\title{
Pertumbuhan Mikroalga Chaetoceros calcitrans Pada Kultivasi dengan Intensitas Cahaya Berbeda
}

\author{
Linggar D. Prasetyo, Endang Supriyantini*, Sri Sedjati \\ Departemen Ilmu Kelautan, Fakultas Perikanan dan Ilmu Kelautan, Universitas Diponegoro \\ Jl. Prof. Sudarto, SH, Tembalang, Semarang, Jawa Tengah, 50275 Indonesia \\ Email: supri_yantini@yahoo.com
}

\begin{abstract}
Abstrak
Chaetoceros calcitrans merupakan mikroalga yang dapat digunakan sebagai pakan alami. Pertumbuhan mikroalga dipengaruhi oleh beberapa faktor, salah satunya adalah intensitas cahaya. Penelitian ini bertujuan untuk mengetahui intensitas cahaya yang dapat menghasilkan pertumbuhan terbaik pada mikroalga $C$. calcitrans. Penelitian menggunakan rancangan acak lengkap (RAL) dengan dua kali pengulangan. Penelitian ini menggunakan perlakuan (intensitas cahaya) dengan empat taraf perlakuan yaitu 1000 (kontrol), 1500, 2000 dan 2500 lux dengan durasi pencahayaan 12 terang : 12 gelap. Sumber cahaya menggunakan lampu TL 18 watt phillips (setara dengan 1421 lux) dan 20 watt general electric (setara dengan 1218 lux). Perhitungan kepadatan dan pengukuran parameter kualitas air dilakukan setiap hari selama proses kultivasi. Pemanenan dilakukan pada fase stasioner. Hasil penelitian menunjukkan bahwa intensitas cahaya yang berbeda mempengaruhi pertumbuhan mikroalga C. calcitrans $(\mathrm{p}=0,000)$. Intensitas cahaya 2500 lux pada kultur $C$. calcitrans skala medium $(60 \mathrm{~L})$ dapat menghasilkan pertumbuhan tertinggi pada hari ke-10 yaitu $67 \times 10^{5} \mathrm{sel} / \mathrm{ml}$ dan biomasa kering 13,75 g. Intensitas cahaya 2000 lux menghasilkan pertumbuhan tertinggi pada hari ke-10 yaitu $52 \times 10^{5} \mathrm{sel} / \mathrm{ml}$ dan biomasa kering $13,70 \mathrm{~g}$. Intensitas cahaya 1500 lux menghasilkan pertumbuhan tertinggi pada hari ke-9 yaitu $47,5 \times 10^{5} \mathrm{se} / \mathrm{ml}$ dan biomasa kering $11,80 \mathrm{~g}$. Intensitas cahaya 1000 lux menghasilkan pertumbuhan tertinggi pada hari ke-8 yaitu $38,5 \times 10^{5} \mathrm{sel} / \mathrm{ml}$ dan biomasa kering $11,50 \mathrm{~g}$. Semakin tinggi intensitas cahaya yang diberikan hingga batas tertentu, maka semakin tinggi pula biomasa kering yang dihasilkan.
\end{abstract}

Kata kunci : Chaetoceros calcitrans, pertumbuhan, intensitas cahaya

\section{Abstract \\ Growth of Chaetoceros calcitrans Microalgae in Cultivation with Different Light Intensities}

Chaetoceros calcitrans can be used for natural food in aquaculture. Microalgae growth is influenced by several factors, one of which is light intensity. Research aims to determine the intensity of light that can produce the best growth in $C$. calcitrans microalgae. The study used a completely randomized design (CRD) with two replications.This study uses a treatment (light intensity) with four levels of treatment, namely 1000 (control), 1500, 2000 and 2500 lux with a duration of lighting 12 hours light: 12 hours dark. The light source uses 18 watt phillips TL lamps (equivalent to 1421 lux) and 20 watts general electric (equivalent to 1218 lux). Calculation of density and measurement of water quality parameters are carried out every day during the cultivation process. Harvesting is done in a stationary phase. The results showed that different light intensities affected the growth of $C$. calcitrans microalgae $(\mathrm{p}=0,000)$. The light intensity of 2500 lux in medium scale C. calcitrans $(60 \mathrm{~L})$ culture could produce the highest growth on day 10 , is $67 \times 10^{5}$ cells $/ \mathrm{ml}$ and biomass $13,75 \mathrm{~g}$. The Light intensity of 2000 lux produced the highest growth on day 10 , is $52 \times 10^{5}$ cells $/ \mathrm{ml}$ and biomass $13.70 \mathrm{~g}$. The Light intensity 1500 lux resulted in the highest growth on day 9 , is $47.5 \times 10^{5} \mathrm{cell} / \mathrm{ml}$ and biomass $11.80 \mathrm{~g}$. The light intensity 1000 lux resulted in the highest growth on day 8 , is $38.5 \times 105$ cells $/ \mathrm{ml}$ and biomass $11.50 \mathrm{~g}$. The higher the light intensity given to a certain limit, the higher the biomass produced.

Keywords : Chaetoceros calcitrans, growth, light intensity 


\section{PENDAHULUAN}

Mikroalga merupakan biota perairan yang berfungsi sebagai sumber pakan alami berbagai jenis larva ikan dan udang. Mikroalga yang berpotensi untuk dikembangkan dan mudah ditemukan di perairan Indonesia, salah satunya yaitu Chaetoceros sp. (Setyaningsih et al., 2012). Chaetoceros sp. sering digunakan sebagai pakan alami karena mempunyai kandungan karbohidrat, protein dan lipid yang cukup tinggi untuk pertumbuhan larva. Mikroalga Chaetoceros calcitrans mempunyai kandungan protein sebesar $35 \%$ dan lipid 14 - 17\% (Helm et al., 2004 ; Kordi, 2010; Mata et al., 2010). Chaetoceros sp. banyak digunakan sebagai pakan alami pada unitunit pembenihan karena selain kandungan protein yang cukup tinggi, pada kondisi lingkungan yang cocok kepadatan dari pakan alami ini cepat meningkat (Isnansetyo dan Kurniastuty, 1995).

Pertumbuhan Chaetoceros sp. dipengaruhi oleh kondisi lingkungan kultivasi, baik faktor fisika maupun kimia. Faktor - faktor yang mempengaruhi pertumbuhan mikroalga di antaranya yaitu intensitas cahaya, suhu, salinitas, nutrien, $\mathrm{pH}$ dan faktor lainnya (Hadiyanto dan Azim, 2012). Mikroalga melakukan proses fotosintesis dengan bantuan energi cahaya untuk pertumbuhan. Cahaya merupakan sumber energi pada proses fotosintesis, tetapi energi yang diberikan oleh cahaya bergantung pada kualitas cahaya, intensitas cahaya dan fotoperiod (Muyassaroh et al., 2018).

Intensitas cahaya merupakan faktor utama dan sekaligus faktor pembatas bagi proses fotosintesis mikroalga. Pada saat intensitas cahaya meningkat, maka mikroalga akan merespon dengan proses reproduksi dan pembelahan sel yang cepat. Pada kondisi yang demikian intensitas cahaya menjadi faktor utama bagi proses reproduksi sel mikroalga (Facta, 2006; Sinaga et al., 2020). Cahaya dapat meningkatkan ATP yang dihasilkan pada proses fotosintesis, naiknya ATP akan memicu pertumbuhan sel alga (Peri et al., 2009). Penelitian yang dilaporkan oleh Padang et al. (2013), bahwa perlakuan intensitas cahaya 15.000 lux memberikan puncak kepadatan sel tertinggi pada kultivasi Navicula sp. dibandingkan perlakuan intensitas cahaya 10.000 lux dan 5000 lux. Sinaga et al. (2020), melaporkan intensitas cahaya yang semakin tinggi akan menghasilkan laju pertumbuhan Nannochloropsis sp. yang semakin rendah. Menurut Peri et al. (2009), intensitas cahaya yang terlalu tinggi (11.700 lux) akan menurunkan kepadatan sel dibandingkan dengan intensitas cahaya 7.400 lux dan 3.400 lux, hal ini dikarenakan intensitas cahaya yang terlalu tinggi akan berpengaruh dengan meningkatnya suhu dan salinitas sehingga fitoplankton memiliki kendala dalam pertumbuhan yang berakibat pada rendahnya kepadatan populasi sel. Pada prinsipnya semua perlakuan intensitas cahaya dapat ditolerir oleh mikroalga untuk dapat tumbuh, namun respon fisiologis dan biokimia berbeda-beda (kepadatan sel, biomassa, metabolitnya). Berdasarkan uraian tersebut penelitian ini dilakukan bertujuan untuk mengetahui pengaruh intensitas cahaya yang berbeda terhadap pertumbuhan mikroalga Chaetoceros calcitrans sehingga diharapkan dapat menjamin ketersediaan pakan alami tersebut pada saat dibutuhkan.

\section{MATERI DAN METODE}

Penelitian ini dilaksanakan pada bulan Januari - April 2019 di Laboratorium Kesehatan Ikan dan Lingkungan, Balai Perikanan Budidaya Air Payau (BPBAP), Situbondo. Rancangan percobaan yang digunakan dalam penelitian ini yaitu rancangan acak lengkap (RAL) menggunakan 1 perlakuan (intensitas cahaya) dengan 4 taraf perlakuan yaitu 1000 (Kontrol), 1500, 2000 dan 2500 lux dan setiap taraf perlakuan dilakukan 2 kali pengulangan. Akuarium yang digunakan untuk percobaan berjumlah 8 buah dengan kapasitas volume $125 \mathrm{~L}$, dibagi menjadi empat kelompok yang merepresentasikan kontrol dan perlakuan. Media kultivasi menggunakan air laut yang sudah disaring menggunakan filter bag dan disterilisasi dengan kaporit dengan dosis 20 ppm (BPBAP Situbondo, 2017). Air laut dinetralkan terlebih dahulu dengan Natrium thiosulfate $5 \mathrm{ppm}$ sebelum digunakan (BPBAP Situbondo, 2017). Air laut yang digunakan untuk media kultivasi sebanyak $60 \mathrm{~L}$ dimasukkan ke dalam setiap akuarium. Periode pencahayaan pada kultivasi mikroalga $C$. calcitrans disesuaikan dengan kondisi di alam, yaitu 12 jam terang : 12 jam gelap (Lim dan Zaleha, 2013). Pencahayaan pada penelitian ini menggunakan lampu TL 18 watt (setara 1.421 lux) dan 20 watt (setara 1.218 lux). Lampu TL yang digunakan adalah yang berwarna putih (Kusdarwati et al., 2011; Sopian et al., 2019). 


\section{Kepadatan Awal Mikroalga C. calcitrans}

Mikroalga $C$. calcitrans diperoleh dari stok murni Laboratorium Pakan Alami, BPBAP, Situbondo, Jawa Timur. Volume inokulan yang dibutuhkan untuk penebaran awal, dihitung berdasarkan rumus Chien (1992). Volume inokulan yang diperoleh berdasarkan hasil perhitungan kepadatan awal starter atau kultivasi murni yang selanjutnya akan dimasukkan ke dalam masing-masing akuarium, kepadatan awal dalam penelitian ini adalah $3 \times 10^{6} \mathrm{sel} / \mathrm{ml}$ (Trikuti et al.,2016).

\section{Kultivasi C. calcitrans}

Mikroalga C. calcitrans dikultivasi selama 14 hari (Sureshkumar et al., 2014). Volume kultivasi sebanyak $60 \mathrm{~L}$ /akuarium, menggunakan akuarium ukuran 50x50x50 cm. Pupuk yang diberikan adalah komposisi pupuk diatom sebanyak 1 kali selama 1 siklus pertumbuhan dengan dosis $1 \mathrm{ml} / \mathrm{L}$ air media (BPBAP Situbondo,2017). Komposisi pupuk dalam 1000 $\mathrm{ml}$ aquadest $\left(\mathrm{NaH}_{2} \mathrm{PO}_{4} 5 \mathrm{~g} ; \mathrm{KNO}_{3} 75 \mathrm{~g} ; \mathrm{Na}_{2}\right.$ EDTA $5 \mathrm{~g} ; \mathrm{FeCl}_{3} 3,15 \mathrm{~g}$; vit $\mathrm{B} 1100 \mathrm{mg}$; vit $\mathrm{B}_{12} 5 \mathrm{mg}$; dan silikat $30 \mathrm{~g}$ ). Aerasi dilakukan untuk menghomogenkan pupuk dengan air media. Selain itu aerasi juga diperlukan agar tidak terjadi pengendapan sel, nutrien tersebar dengan baik sehingga mikroalga dalam kultur mendapatkan nutrien yang sama, mencegah stratifikasi suhu, dan meningkatkan pertukaran gas dari udara ke media mikroalga (Taw, 1990). Bibit C. calcitrans dimasukkan ke dalam masing-masing akuarium dengan kepadatan awal $3 \times 10^{6} \mathrm{sel} / \mathrm{ml}$ (Trikuti et al.,2016). Lampu di pasang pada bagian atas wadah kultivasi. Sumber lampu berasal dari lampu dengan merk yang berbeda yaitu lampu TL 18 watt phillips (setara dengan 1.421 lux) dan 20 watt general electric (setara dengan 1.218 lux). Pengaturan intensitas cahaya yang berbeda dilakukan dengan menyesuaikan jarak sumber cahaya dengan permukaan air pada saat kultivasi. Pengukuran besar intensitas cahaya (satuan lux) setiap taraf perlakuan menggunakan lux meter. Sensor cahaya lux meter di letakkan pada bagian dalam wadah kultivasi untuk mengukur intensitas cahaya sesuai taraf perlakuan, sehingga jarak wadah kultivasi dengan sumber cahaya dapat disesuaikan. Selama proses kultivasi dilakukan aerasi yang dipasang di bagian tengah akuarium dengan posisi menggantung dengan jarak $\pm 2 \mathrm{~cm}$ dari dasar akuarium. Pengukuran kualitas air media (suhu, salinitas, $\mathrm{pH}$, intensitas cahaya) dilakukan setiap hari pada pukul 09.00 WIB untuk fase terang dan pukul 21.00 WIB untuk fase gelap. Lingkungan kultur yang diharapkan selama penelitian ini adalah suhu $29-35^{\circ} \mathrm{C}$, salinitas 30 $35 \mathrm{ppt}$, dan $\mathrm{pH}$ 8-9,5 yang merupakan lingkungan kultur yang baik bagi Chaetoceros sp. (Sopian et al., 2019). Perhitungan kepadatan sel $C$. calcitrans dilakukan setiap hari pada pukul 09.00 WIB dan dilakukan di bawah mikroskop binokuler dengan perbesaran $40 \times 10$. Perhitungan kepadatan sel mikroalga menggunakan haemocytometer (Improved Neubauer) dan hand counter (Liliandari dan Aunurohim, 2013). Penghitungan kepadatan sel ini dilakukan sehari setelah 24 jam penebaran awal hingga pertumbuhan mencapai fase kematian mikroalga C. calcitrans (Padang et al., 2013). Perhitungan kepadatan mikroalga dilakukan menggunakan rumus Hadioetomo (1993). Hasil pengamatan kepadatan sel mikroalga dijadikan sebagai pedoman dalam menentukan pola dan kurva pertumbuhan, sehingga dapat dilakukan proses pemanenan.

\section{Pemanenan Mikroalga}

Pemanenan $C$. calcitrans dilakukan pada waktu memasuki fase stasioner (Widyaningrum et al., 2013). Pemanenan dilakukan menggunakan metode flokulasi menggunakan aluminium sulfat $\left(\mathrm{Al}_{2}\left(\mathrm{SO}_{4}\right)_{3}\right)$ dengan dosis $0,2 \mathrm{~g} / \mathrm{L}$ (Hidayati et al., 2015). Selanjutnya sampel didiamkan selama 1 malam untuk mengendapkan biomassa, apabila biomassa sudah mengendap air pada bagian atas disiphon sampai setengah bagian, kemudian dilanjutkan dengan penyaringan menggunakan kain berukuran mesh 400 mikron. Pengeringan biomassa menggunakan metode sun drying ( \pm 1 2 hari) (Amini et al., 2011).

\section{Analisis Data}

Semua data yang diperoleh berupa data kepadatan sel dan biomasa dianalisis menggunakan uji One way ANOVA dengan selang kepercayaan $95 \%$. Data terlebih dahulu diuji normalitas dan homogenitasnya menggunakan uji Kolmogorov-Smirnov dan uji levene. Jika hasil analisis berbeda nyata, dilanjutkan dengan uji Tukey's. Besar pengaruh variabel perbedaan intensitas cahaya terhadap pertumbuhan C. calcitrans diestimasi menggunakan regresi linier. 


\section{HASIL DAN PEMBAHASAN}

\section{Pertumbuhan C. Calcitrans}

Pertumbuhan mikroalga $C$. calcitrans yang dikultivasi selama 14 hari dengan intensitas cahaya berbeda dapat diketahui secara kualitatif maupun kuantitatif. Secara kualitatif melalui pengamatan perubahan warna media kultivasi, sedangkan secara kuantitatif melalui perhitungan kepadatan sel mikroalga. Hasil penelitian ini menunjukkan bahwa mikroalga $C$. calcitrans mengalami pertumbuhan, hal ini dapat diketahui melalui pengamatan perubahan warna media kultivasi. Warna media kultivasi berubah dari coklat keemasan menjadi coklat gelap seiring dengan bertambahnya waktu kultivasi. Warna coklat keemasan pada kultivasi diduga karena $C$. calcitrans termasuk diatom yang mempunyai kandungan pigmen karotenoid dominan. Warna media pada kultivasi fitoplankton merupakan warna dari pigmen utama yang terdapat pada sitoplasma sel (Prihantini et al., 2007). Pigmen karotenoid sebagai pigmen dominan dan memberikan warna coklat keemasan diduga karena pigmen karotenoid menyerap cahaya hijau dan memantulkan warna jingga, kuning dan merah (Campbell dan Reece, 2008; Maleta et al., 2018).

Hasil penelitian menunjukkan bahwa pertumbuhan $C$. calcitrans diketahui secara kuantitatif melalui perhitungan kepadatan sel.
Pertumbuhan C. calcitrans setiap perlakuan intensitas cahaya mempunyai nilai yang bervariasi (Tabel 1). Pertumbuhan sel tertinggi yaitu intensitas cahaya 2500 lux dengan kepadatan sel $67 \times 10^{5} \mathrm{sel} / \mathrm{ml}$ hari ke 10 kultivasi, sedangkan pertumbuhan terendah yaitu intensitas cahaya 1000 lux dengan kepadatan sel $38,5 \times 10^{5} \mathrm{sel} / \mathrm{ml}$ hari ke 8 kultivasi. Hasil uji statistik one way ANOVA menunjukkan bahwa intensitas cahaya berbeda berpengaruh nyata terhadap pertumbuhan C. calcitrans $(\mathrm{p}<0,05)$.

Hasil uji Tukey HSD menunjukkan bahwa setiap taraf perlakuan intensitas cahaya mempunyai pengaruh yang berbeda terhadap pertumbuhan $C$. calcitrans ditunjukkan dengan huruf superscript yang berbeda setiap taraf perlakuan intensitas cahaya (Tabel 2).

Analisis regresi dilakukan untuk mengetahui hubungan intensitas cahaya berbeda terhadap pertumbuhan mikroalga $C$. calcitrans (Gambar 1). Hasil analisis regresi yaitu persamaan $\mathrm{y}=0,015 \mathrm{x}+14,832$ dan nilai dari $\mathrm{R}^{2}=0,978$, sedangkan nilai dari $\mathrm{r}=0,989$.

Pertumbuhan sel $C$. calcitrans membentuk sebuah pola dan terbagi menjadi beberapa tahapan atau fase, yaitu fase lag, eksponensial, stasioner dan kematian. Fase pertumbuhan $C$. calcitrans selama 14 hari proses kultivasi membentuk kurva pertumbuhan (Gambar 2).

Tabel 1. Kepadatan C. Calcitrans selama kultivasi 14 hari dengan taraf intensitas cahaya berbeda

\begin{tabular}{ccccc}
\hline \multirow{2}{*}{ Hari Ke- } & \multicolumn{4}{c}{ Kepadatan Sel $\left(\mathrm{x} 10^{5} \mathrm{sel} / \mathrm{ml}\right)$} \\
\cline { 2 - 5 } & $1000 \mathrm{lux}$ & $1500 \mathrm{lux}$ & $2000 \mathrm{lux}$ & $2500 \mathrm{lux}$ \\
\hline 1 & $30 \pm 0,00$ & $30 \pm 0,00$ & $30 \pm 0,00$ & $30 \pm 0,00$ \\
2 & $31 \pm 1,00$ & $30,5 \pm 0,50$ & $32,5 \pm 1,50$ & $31,5 \pm 0,50$ \\
3 & $29,5 \pm 3,50$ & $31,5 \pm 1,50$ & $42 \pm 3,00$ & $41 \pm 1,00$ \\
4 & $29,5 \pm 0,50$ & $33,5 \pm 3,50$ & $46 \pm 5,00$ & $52 \pm 4,00$ \\
5 & $32 \pm 3,00$ & $39,5 \pm 0,50$ & $46,5 \pm 2,50$ & $54 \pm 3,00$ \\
6 & $34 \pm 0,00$ & $42,5 \pm 4,50$ & $51,5 \pm 4,50$ & $54,5 \pm 3,00$ \\
7 & $34,5 \pm 1,50$ & $43,5 \pm 3,50$ & $46 \pm 5,00$ & $60 \pm 3,00$ \\
8 & $\left.38,5 \pm 2,50^{*}\right)$ & $46 \pm 4,00$ & $47 \pm 1,00$ & $66 \pm 5,00$ \\
9 & $32,5 \pm 2,50$ & $\left.47,5 \pm 4,50^{*}\right)$ & $49,5 \pm 0,50$ & $65 \pm 4,00$ \\
10 & $\left.31 \pm 2,00^{* *}\right)$ & $40 \pm 2,00$ & $\left.52 \pm 3,00^{*}\right)$ & $\left.67 \pm 5,00^{*}\right)$ \\
11 & $30 \pm 1,00$ & $\left.38 \pm 2,00^{* *}\right)$ & $47,5 \pm 5,50$ & $63,5 \pm 4,50$ \\
12 & $27,5 \pm 0,50$ & $36 \pm 1,00$ & $\left.47 \pm 1,00^{* *}\right)$ & $\left.54 \pm 4,00^{* *}\right)$ \\
13 & $24,5 \pm 0,50$ & $30 \pm 2,00$ & $44,5 \pm 3,50$ & $52 \pm 5,00$ \\
14 & $18 \pm 4,00$ & $29,5 \pm 3,50$ & $42 \pm 2,00$ & $47 \pm 5,00$ \\
\hline
\end{tabular}

Keterangan : (*) menunjukkan puncak kepadatan; (**) menunjukkan waktu pemanenan 
Tabel 2. Kepadatan sel mikroalga pada fase puncak eksponensial yang dikultivasi selama 14 hari dengan intensitas cahaya berbeda

\begin{tabular}{cc}
\hline Perlakuan Taraf Intensitas Cahaya (lux) & $\begin{array}{c}\text { Rata - Rata Kepadatan Sel Mikroalga C. calcitrans } \\
\left(\text { x } 10^{5} \mathrm{sel} / \mathrm{ml}\right)\end{array}$ \\
\hline 1000 & $38,5^{\mathrm{a}} \pm 2,50$ \\
1500 & $47,5^{\mathrm{b}} \pm 4,50$ \\
2000 & $52^{\mathrm{c}} \pm 3,00$ \\
2500 & $67^{\mathrm{d}} \pm 5,00$ \\
\hline
\end{tabular}

Keterangan: Huruf superscrip yang berbeda pada kolom yang sama menunjukkan perbedaan nyata $(\mathrm{p}<0,05)$

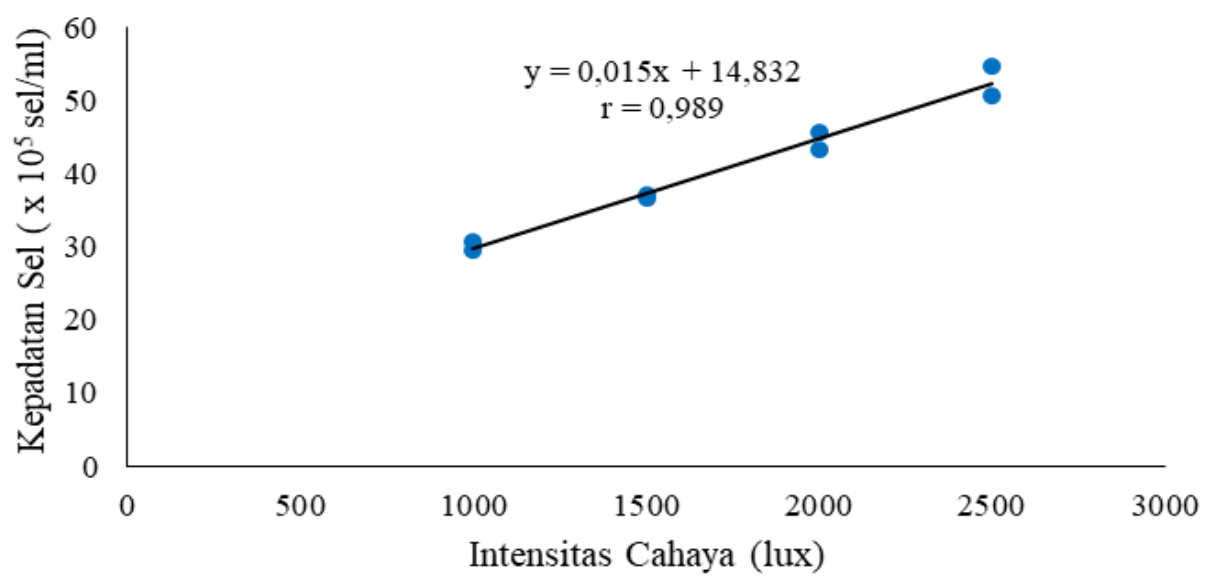

Gambar 1. Hubungan antara intensitas cahaya berbeda terhadap pertumbuhan Rata-rata C. calcitrans selama masa kultivasi

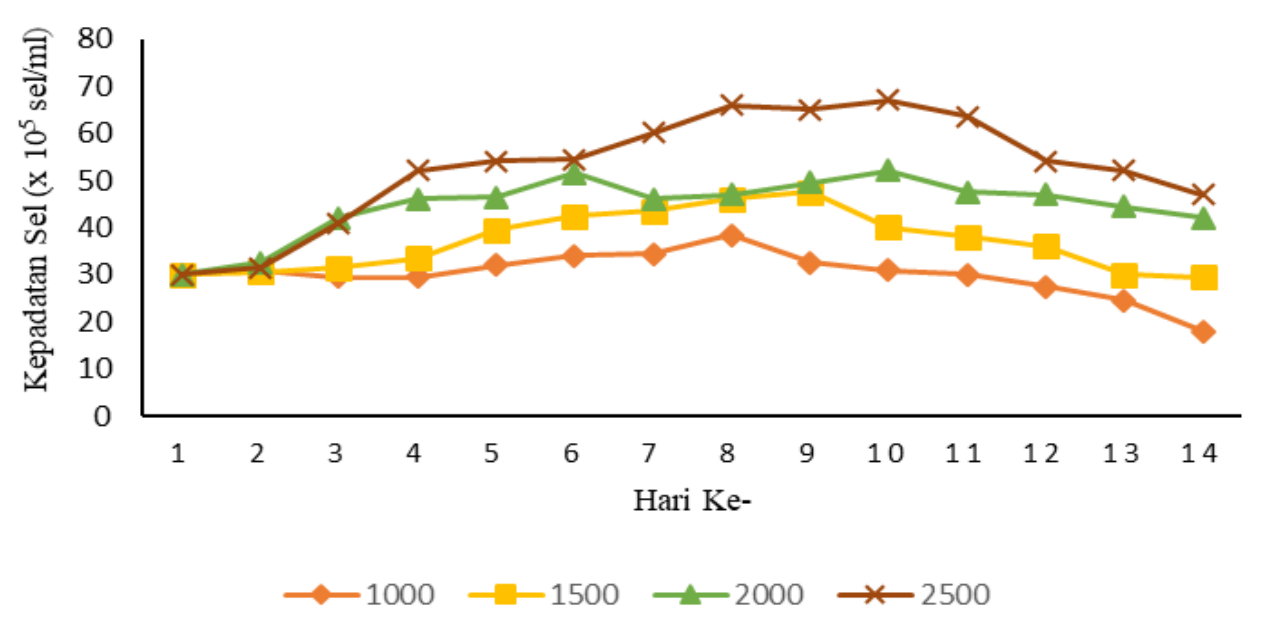

Gambar 2. Pola pertumbuhan mikroalga $C$. calcitrans pada kultivasi selama 14 hari dengan intensitas cahaya berbeda

Kepadatan sel tertinggi pada penelitian ini diperoleh pada intensitas cahaya (2500 lux). Hal ini diduga karena pigmen fotosintesis mampu menyerap energi foton lebih banyak, sehingga meningkatkan laju fotosintesis dan senyawa organik yang dihasilkan lebih banyak untuk digunakan mikroalga C. calcitrans dalam melakukan pertumbuhan dan reproduksi. Menurut Lavens dan Surgeloos (1996), aktivitas fotosintesis akan meningkat seiring dengan kenaikan intensitas cahaya, akibatnya senyawa organik yang dihasilkan menjadi lebih cepat. 
Umumnya intensitas cahaya yang lebih besar akan lebih efektif untuk proses fotosintesis, tetapi pada tingkat cahaya yang sangat tinggi dapat mengurangi laju proses tersebut (Sudhakar et al., 2011). Hasil penelitian Febriani et al. (2020), intensitas cahaya yang terlalu tinggi (11.700 lux) akan menurunkan kepadatan sel dibandingkan dengan intensitas cahaya 7.400 lux dan 3.400 lux. Sebaliknya pada intensitas cahaya (1000 lux) pigmen fotosintesis tidak optimal dalam menyerap energy foton sehingga senyawa organik yang dihasilkan sedikit hanya mampu untuk pertumbuhan sel saja. Menurut Wu (2016), intensitas cahaya dapat menyebabkan menurunnya laju fotosintesis. Sel fitoplankton akan efektif bekerja menyerap energy cahaya pada intensitas yang sesuai, sedangkan intensitas cahaya yang tidak sesuai dapat menyebabkan energy cahaya yang terserap menjadi kurang efektif (Sunarto, 2004). Muchammad et al. (2013) melaporkan, pada intensitas cahaya 2500 dan 4000 luxs pertumbuhan sel Ankistrodesmus sp.mengalami kenaikan namun pada intensitas cahaya 5000 luxs mengalami penurunan. Menurut Chinnasamy et al. (2009) semakin tinggi intensitas cahaya maka memberikan sejumlah besar energi untuk mikroalga dalam melakukan fotosintesis.Hal ini dapat terjadi karena cahaya yang lebih tinggi menyumbangkan lebih banyak elektron (e-) untuk bergabung dengan atom $\mathrm{H}^{+}$ dan $\mathrm{O}_{2}$ menghasilkan energi. Sedangkan pertumbuhan sel mikroalga mulai terhambat apabila intensitas cahaya mulai dinaikkan menjadi 5000 luks.Pertumbuhan mikroalga terdiri dari beberapa fase, yaitu fase lag (adaptasi), eksponensial, penurunan laju pertumbuhan, stasioner dan kematian. Hasil penelitian ini menunjukkan bahwa setiap fase pertumbuhan $C$. calcitrans pada kultivasi dengan perbedaan taraf intensitas cahaya mempunyai variasi waktu dalam setiap fasenya. Variasi waktu ini diduga adanya pengaruh intensitas cahaya yang berbeda, sehingga mikroalga $C$. calcitrans dalam melakukan adaptasi sesuai dengan kemampuannya untuk bertahan hidup pada intensitas cahaya tersebut $(1000,1500,2000$ dan 2500 lux) selama proses kultivasi, hal ini dapat dilihat pada pola pertumbuhan mikroalga $C$. calcitrans (Gambar 2). Pada penelitian Febriani et al. (2020), kultivasi Dunaliella salina dengan perlakuan intensitas cahaya 2.500, 3.500, 4.500, dan 5.500 luxs menunjukkan fase lag terjadi pada hari pertama, sedangkan fase eksponensial untuk intensitas cahaya 2.500 dan 3500 luxs terjadi pada hari ke-2 hingga hari ke- 8 , dan intensitas cahaya 4500 dan 5500 luxs kepadatan rata-rata sel $D$. salina terjadi lebih cepat yaitu pada hari ke-2 hingga hari ke-7. Fase kematian untuk intensitas cahaya 2500 dan 3500 luxs terjadi pada hari ke-9 hingga hari ke-10, sedangkan intensitas cahaya 4500 dan 5500 luxs terjadi pada hari ke-8 sampai hari ke-10. Menurut Chinnasamy et al. (2009),fase kematian terjadi akibat laju kematian lebih cepat dibandingkan laju pertumbuhan sehingga terjadi penurunan jumlah sel.

Hasil penelitian ini menunjukkan bahwa terdapat perbedaan interval waktu fase adaptasi (lag) pada intensitas 1000, 1500 dan 2500 lux secara berturut - turut yaitu 3, 2 dan 1 hari, sedangkan 2000 lux tidak terlihat fase adaptasinya, hal ini diduga karena perbedaan intensitas cahaya. Intensitas cahaya yang rendah menyebabkan pertumbuhan $C$. calcitrans menjadi lambat. Hasil fotosintesis yang digunakan untuk pertumbuhan menjadi rendah, sehingga membutuhkan waktu agar hasil fotosintesis cukup digunakan untuk meningkatkan kepadatan sel. Intensitas cahaya 2000 lux tidak terlihat fase adaptasinya karena intensitas cahaya yang digunakan sama pada saat kultivasi starter yaitu 2000 lux. Wang et al. (2012), menyatakan bahwa fase adaptasi akan berlangsung lebih cepat atau tidak terlihat dan sel akan cepat memasuki fase eksponensial, apabila tidak terjadi perbedaan kondisi lingkungan dan nutrien pada kultivasi starter dengan kultivasi media percobaan. Menurut Istirokhatun et al. (2017), fase adaptasi menjadi lebih singkat apabila mikroalga dapat beradaptasi dengan baik pada lingkungan yang baru.

Hasil penelitian ini menunjukkan bahwa fase eksponensial setiap taraf perlakuan intensitas cahaya memiliki interval waktu yang bervariasi berturut-turut untuk 1000, 1500, 2000 dan 2500 lux yaitu 4, 6, 9 dan 8 hari. Perbedaan waktu eksponensial ini diduga adanya perbedaan intensitas cahaya. Taraf intensitas cahaya yang rendah (1000 lux) menyebabkan waktu eksponensial menjadi lebih singkat (4 hari), hal ini karena fase adaptasi pada kultivasi intensitas cahaya 1000 lux lebih lama dibandingkan intensitas cahaya lainnya. Mikroalga $C$. calcitrans pada fase adaptasi membutuhkan nutrien melalui proses fotosintesis, tetapi intensitas cahaya rendah menyebabkan hasil fotosintesis terbatas untuk pertumbuhan, ketika mikroalga C. calcitrans 
sudah mampu melakukan pembelahan sel (fase eksponensial) nutrien yang tersedia jumlah nya sudah berkurang seiring dengan bertambahnya masa kultivasi. Menurut Kawaroe et al. (2010), fase eksponensial (log phase) diawali dengan pembelahan sel dan ditandai dengan kepadatan populasi yang meningkat. Menurut Sureshkumar et al. (2014), fase puncak eksponensial pertumbuhan $C$. calcitrans terjadi pada hari ke-8 kultivasi dengan taraf intensitas cahaya 2000 lux. Perbedaan fase puncak eksponensial ini diduga karena perbedaan kondisi lingkungan kultivasi (seperti fotoperiod), karena kultivasi C. calcitrans pada penelitian ini menggunakan kondisi 12 jam terang dan 12 jam gelap, sedangkan penelitian Sureshkumar et al. (2014), mikroalga $C$. calcitrans dikultivasi dengan kondisi 24 jam terang.

Fase selanjutnya yaitu fase penurunan laju pertumbuhan. Waktu penurunan laju pertumbuhan setiap perlakuan intensitas cahaya bervariasi. Fase ini terjadi setelah fase puncak eksponensial, hal ini diduga karena populasi mikroalga semakin tinggi, tetapi nutrien pada media kultivasi tidak bertambah dan semakin terbatas jumlahnya sehingga mikroalga kekurangan nutrien dan mati, oleh karena itu terjadi penurunan kepadatan sel mikroalga (Hadiyanto dan Azim, 2012 ; Kurniawan et al., 2017). Fase selanjutnya adalah fase stasioner. Menurut Rafaelina et al. (2016), fase stasioner mikroalga mengalami pertumbuhan yang cenderung konstan. Interval waktu fase penurunan dan fase stasioner umumnya relatif singkat (Istirokhatun et al., 2017).

Pertumbuhan C. calcitrans mengalami fase kematian pada hari ke-13 dan ke-14 kultivasi untuk setiap taraf perlakuan intensitas cahaya. Hal ini ditandai dengan penurunan kepadatan sel setiap harinya. Fase kematian pada penelitian ini diduga karena nutrien pada media kultivasi jumlahnya semakin sedikit sehingga tidak cukup memenuhi kebutuhan sel $C$. calcitrans, oleh karena itu terjadi kematian sel C. calcitrans dalam jumlah besar dan pembelahan sel hampir tidak pernah terjadi. Menurut Salim et al. (2018), fase kematian mikroalga $C$. calcitrans terjadi setelah hari ke-12 kultivasi. Sedangkan menurut Sureshkumar et al. (2014), fase kematian $C$. calcitrans terjadi pada hari ke-13 sampai hari ke14.

Hasil penelitian ini menunjukkan bahwa intensitas cahaya 2500 lux mempunyai puncak kepadatan sel tertinggi, sedangkan penelitian $\mathrm{Pal}$ et al. (2013), menunjukkan bahwa intensitas cahaya 1000 lux mempunyai puncak kepadatan sel tertinggi. Hal ini diduga karena terdapat perbedaan jenis mikroalga yang digunakan, pada penelitian ini menggunakan mikroalga $C$. calcitrans sedangkan penelitian Pal et al. (2013), menggunakan $C$. muelleri. Setiap spesies mikroalga mempunyai toleransi yang berbeda terhadap variasi intensitas cahaya (Huang et al.,2011).

\section{Biomassa C. Calcitrans}

Berdasarkan penelitian yang telah dilakukan diperoleh biomassa basah hasil dari proses flokulasi menggunakan Alumunium sulfat dan penyaringan menggunakan kain satin berukuran mesh 400 mikron, kemudian dikeringkan di bawah sinar matahari $( \pm 1-2$ hari) sehingga diperoleh biomassa kering. Hasil pengamatan menunjukkan bahwa rerata biomassa kering tertinggi pada perlakuan intensitas cahaya 2500 lux yaitu 13,75 gram, selanjutnya berturutturut untuk intensitas cahaya 2000 lux, 1500 lux, dan 1000 lux masing-masing sebesar 13,70 g, $11,80 \mathrm{~g}$, dan 11,50 g (Gambar 3). Hasil uji normalitas dan uji homogenitas pada data biomassa kering sel $C$. calcitrans mempunyai nilai $(p \geq 0,05)$ yang menunjukkan bahwa data kepadatan sel memiliki sebaran normal dan homogen. Hasil uji One Way ANOVA menunjukkan nilai signifikansi 0,494 ( $\mathrm{p} \geq 0,05)$, artinya tidak terdapat pengaruh yang nyata antara taraf perlakuan intensitas cahaya terhadap biomassa kering mikroalga $C$. calcitrans pada tingkat kepercayaan $95 \%(\alpha=0,05)$.

Intensitas cahaya (2500 lux) mempunyai nilai biomassa kering yang lebih tinggi dibanding lainnya, hal ini diduga karena intensitas cahaya yang tinggi menyebabkan laju fotosintesis menjadi lebih cepat, sehingga hasil fotosintesis mencukupi kebutuhan mikroalga yang digunakan untuk pertumbuhan dan pembelahan sel. Menurut Pertamawati (2010), laju fotosintesis akan berjalan maksimum ketika banyak cahaya. Intensitas cahaya (1000 lux) mempunyai nilai biomassa yang lebih rendah, hal ini diduga karena intensitas cahaya yang rendah menyebabkan penurunan laju fotosintesis, sehingga hasil fotosintesis tidak optimal dan biosintesis makromolekul seperti (lipid, protein dan asam nukleat) menjadi rendah, akibat tidak optimalnya sintesis glukosa pada proses fotosintesis (Nielsen $\&$ Nielsen, 2017). Parson dan Chapman (2000), 


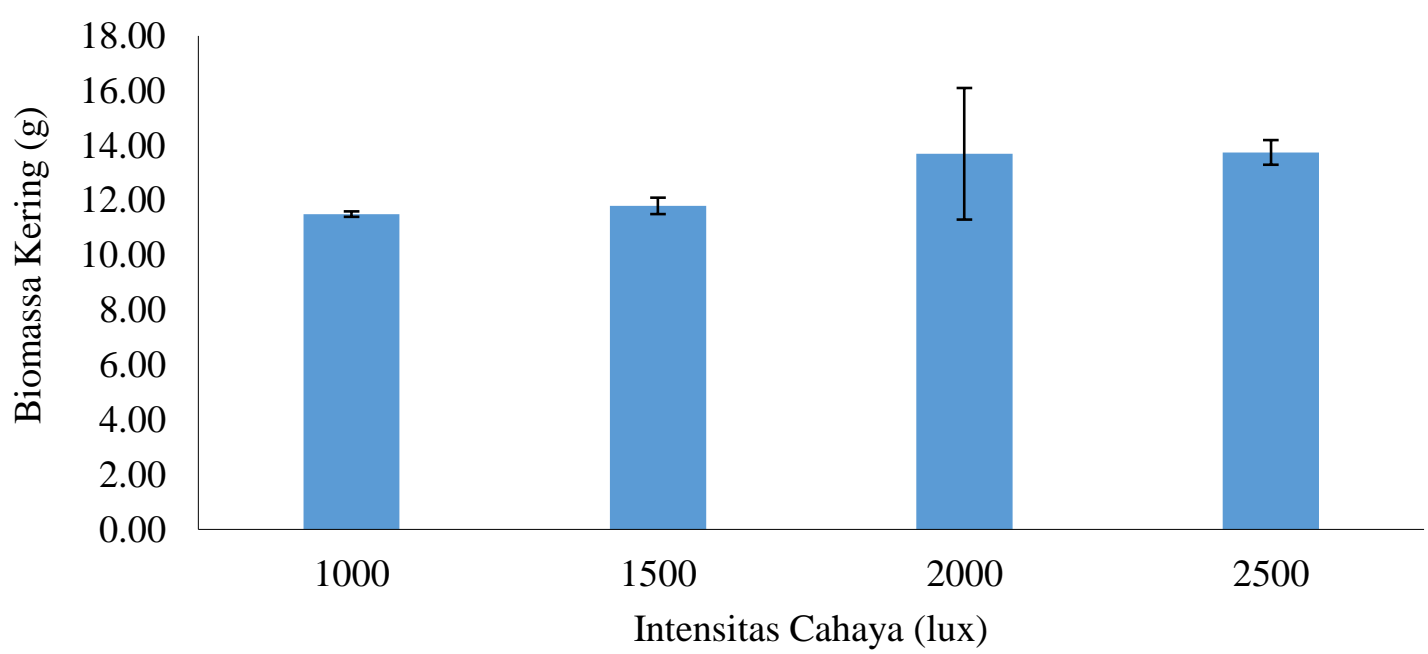

Gambar 3. Nilai rata - rata biomassa kering mikroalga C. calcitrans pada kultivasi selama 14 hari dengan taraf intensitas cahaya berbeda

menyatakan jika intensitas cahaya rendah, maka akan menyebabkan suplai materi kasar yang dihasilkan pada proses fotosintesis akan berkurang. Selanjutnya apabila organisme fotoautotrof mengalami kekurangan cahaya, maka akan berdampak pada menurunnya laju fotosintesis (Nielsen \& Nielsen,2017). Menurunnya laju fotosintesis akan berdampak pula pada jumlah biomassa yang dihasilkan semakin rendah (Pertamawati, 2010; Nielsen \& Nielsen, 2017).

Berdasarkan uji statistik, tidak ada pengaruh nyata $(\mathrm{p} \geq 0,05)$ antara taraf intensitas cahaya yang berbeda terhadap biomassa kering yang dihasilkan (Gambar 3), hal ini diduga berkaitan dengan waktu pemanenan yang dilakukan pada waktu memasuki fase stasioner (akhir eksponensial), sehingga mempengaruhi kepadatan sel mikroalga. Pemanenan yang dilakukan pada fase mendekati stasioner (akhir eksponensial) akan menghasilkan kepadatan sel dengan jumlah yang relative sama. Hal ini disebabkan karena pada fase ini terjadi serapan nutrien dari media secara cepat. Menurut Prayitno (2015), laju pembentukan biomassa yang tinggi terjadi pada fase eksponensial, dimana pada fase ini terjadi serapan nutrisi dari media secara cepat sehingga ketersediaan nutrisi dalam media menjadi berkurang. Kepadatan sel setiap taraf intensitas cahaya mempunyai nilai berbeda $(\mathrm{p}<0,05)$, sedangkan nutrien yang diberikan jumlahnya sama. Mikroalga membutuhkan nutrien untuk melakukan proses pertumbuhan, sehingga terjadi proses peningkatkan ukuran sel. Intensitas cahaya rendah mempunyai kepadatan sel rendah, sehingga nutrien yang tersedia berlebih. Mikroalga pada intensitas cahaya yang rendah mampu menyerap nutrien lebih banyak, oleh karena itu ukuran selnya lebih besar dibandingkan dengan mikroalga pada intensitas cahaya tinggi. Kepadatan sel yang tinggi membutuhkan nutrien dalam jumlah banyak, tetapi nutrien yang diberikan dalam hal ini sama setiap perlakuan. Nutrien yang diserap oleh mikroalga pada intensitas cahaya tinggi jumlahnya terbatas, sehingga ukuran sel menjadi lebih kecil, oleh karena itu ketika dilakukan penimbangan nilai biomassa pada intensitas cahaya rendah maupun tinggi mempunyai nilai yang tidak berbeda nyata. Isnansetyo dan Kuarniastuty (1995), menyatakan pertumbuhan mikroalga ditandai dengan bertambahnya ukuran sel.

\section{Parameter Kualitas Air Laut Media Kultivasi}

Pengukuran parameter kualitas air dilakukan dua kali yaitu pada fase terang (09.00 WIB) dan fase gelap (21.00 WIB) setiap hari selama 14 hari masa kultivasi. Pengukuran parameter kualitas air meliputi pengukuran suhu, salinitas, $\mathrm{pH}$ dan DO. Hasil pengukuran parameter kualitas air yang dilakukan selama 14 hari masa kultivasi masih dalam kisaran normal untuk pertumbuhan mikroalga $C$. calcitrans (Tabel 3).

Hasil pengukuran suhu pada perlakuan intensitas cahaya 2000 lux dan 2500 lux menghasilkan nilai yang cenderung tinggi dibandingkan perlakuan intensitas cahaya 1000 lux dan 1500 lux terutama fase terang. Suhu yang 
Tabel 3. Data parameter kualitas air selama 14 hari kultivasi mikroalga C. calcitrans dengan intensitas cahaya berbeda

\begin{tabular}{cccccc}
\hline Perlakuan (lux) & Fase & Suhu $\left({ }^{\circ} \mathrm{C}\right)$ & Salinitas $(\% 00)$ & DO $(\mathrm{mg} / \mathrm{l})$ & $\mathrm{pH}$ \\
\hline \multirow{2}{*}{1000} & Terang & $25-27$ & 32 & $7,4-8,8$ & $8,12-8,44$ \\
& Gelap & $26-26,8$ & 32 & $7,3-8,7$ & $8,03-8,38$ \\
\multirow{2}{*}{1500} & Terang & $26-27$ & 32 & $7,5-8,8$ & $8,18-8,39$ \\
& Gelap & $26-26,8$ & 32 & $7,4-8,6$ & $8,17-8,37$ \\
& Terang & $25,8-27$ & 32 & $7,6-8,9$ & $8,24-8,43$ \\
\multirow{2}{*}{25000} & Gelap & $25-26,8$ & 32 & $7,2-8,8$ & $8,14-8,40$ \\
& Terang & $26-27,5$ & 32 & $7,8-9,1$ & $8,28-8,52$ \\
& Gelap & $26-26,8$ & 32 & $7,3-8,9$ & $8,14-8,42$ \\
Referensi & & $25-30^{\text {a) }}$ & $25-35^{\text {b) }}$ & $\geq 5^{\text {c) }}$ & $7,9-8,5^{\text {d }}$ \\
\hline
\end{tabular}

Sumber : a) = Adenan et al. $(2013) ; \mathrm{b})=$ BBL (2002) ; c) = Leonard et al. (2017); d) = Banerjee et al. (2011)

tinggi akan mempengaruhi kepadatan sel $C$. calcitrans, hal ini dapat dilihat dari hasil biomassa kering yang didapatkan yaitu $13,70 \mathrm{~g}$ dan $13,75 \mathrm{~g}$ dibandingkan perlakuan lainnya. Menurut Dwirejeki dan Ermavitalini (2019), peningkatan suhu hingga batas tertentu menyebabkan pertumbuhan mikroalga menjadi lebih cepat dalam mencapai fase puncak (stasioner). Suhu yang tinggi akan mempercepat aktifitas fotosintesis. Menurut Gammanpila \& Rupasinghe (2015), cahaya terang pada proses fotosintesis digunakan pada waktu proses fotokimia untuk menghasilkan ATP dan NADPH, sedangkan cahaya gelap untuk reaksi biokimia dalam sintesis molekul esensial untuk pertumbuhan.

\section{KESIMPULAN}

Intensitas cahaya yang berbeda mempengaruhi pertumbuhan mikroalga $C$. calcitrans $(\mathrm{p}=0,000)$. Intensitas cahaya 2500 lux pada kultur $C$. calcitrans dapat menghasilkan pertumbuhan tertinggi pada hari ke-10 yaitu $67 \mathrm{x}$ $10^{5} \mathrm{sel} / \mathrm{ml}$ dan biomasa kering 13,75 gram. Intensitas cahaya 2000 lux menghasilkan pertumbuhan tertinggi pada hari ke-10 sebesar $52 \times 10^{5} \mathrm{sel} / \mathrm{ml}$ dan biomasa kering $11,50 \mathrm{~g}$. Intensitas cahaya 1500 lux pertumbuhan tertinggi dicapai pada hari ke-9 sebesar $47,5 \times 10^{5} \mathrm{sel} / \mathrm{ml}$ dan biomasa kering 11,80 g. Intensitas cahaya 1000 lux pertumbuhan tertinggi dicapai pada hari ke- 8

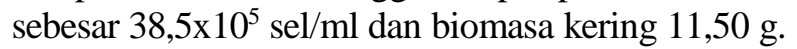
Semakin tinggi intensitas cahaya yang diberikan hingga batas tertentu semakin tinggi pula biomasa kering yang dihasilkan.

\section{DAFTAR PUSTAKA}

Amini, S., Sugiyono dan Saadudin, E., 2011. Kandungan Minyak Botryococcus braunii, Nanochloropsis sp., dan Spirulina platensis pada Umur yang Berbeda. Jurnal Pascapanen dan Bioteknologi Kelautan dan Perikanan, 6(1):39-43. doi: 10.15578/jpbkp. v6i1.91

Balai Budidaya Air Payau (BPBAP) Situbondo. 2017. Petunjuk Teknis Produksi Phytoplankton. Dirjen Perikanan Budidaya, Kementrian Kelautan Perikanan, $58 \mathrm{hlm}$.

Campbell, N. A., dan Reece, J. B., 2008. Biology. Ed.VIII. Erlangga, Jakarta, $486 \mathrm{hlm}$. (Diterjemahkan oleh Damaring Tyas Wulandari).

Chien, Y. H. 1992. Water Quality Requirement and Management for Marine Shrimp Culture. Water Quality Management, 144-151.

Chinnasamy, S., Ramakrishnan, B., Bhatnagar, A., \& Das, K.C., 2009. Biomass Production Potential of a Wastewater Alga Chorella vulgaris ARC 1 Under Elevated Levels of $\mathrm{CO}_{2}$ and Temperature. International Journal of Molecular Science, 10:518-532. doi: 10.3390/ijms10020518

Dwirejeki, S., \& Ermavitalini, D., 2019. Pengaruh Cekaman Nitrogen dan Fotoperiode terhadap Kurva Pertumbuhan Kultur Nannochloropsis. sp., Jurnal Sains dan Seni ITS, 8(1):13-18, doi: 10.12962/j23373520.v8i1.41642

Facta, 2006. Pengaruh Pengaturan Intensitas Cahaya yang Berbeda terhadap Kelimpahan 
Sel Dunnallella sp. dan Oksigen Terlarut dengan Simulator TRIAC dan Mikrokontroler AT89852. Jurnal Ilmu Kelautan, 11(2): 67-71.

Febriani, R., Hasibuan, S., \& Syafriadiman. 2020. Pengaruh Intensitas Cahaya Berbeda terhadap Kepadatan dan Kandungan Karotenoid Dunaliella salina. Jurnal Perikanan dan Kelautan, 25(1):36-43. doi: 10.31258/jpk.25.1.36-43

Gammanpila, M. \& Rupasinghe, C.P. 2015. Light Intensity and Photoperiode Effect on Growth and Lipid Accumulation of Microalgae Chlorella vulgaris and Nannochloropsis sp. For Biodiesel Production, in Proccedings of $12^{\text {th }}$ ISERD International Conference, pp. 5155.

Hadioetomo, R.S. 1993. Mikrobiologi Dasar dalam Praktek, Teknik dan Prosedur Dasar Laboratorium. Gramedia Pustaka Utama, Jakarta, 163 hlm.

Hadiyanto dan Azim, M., 2012. Mikroalga Sumber Pangan dan Energi Masa Depan. UPT UNDIP Press, Semarang, $126 \mathrm{hlm}$.

Helm, M. M., Bourne, N., \& Lovatelli, A., 2004. Hatchery Culture of Bivalves : A Practical Manual. FAO Fisheries Technical Paper Number 471. Rome, Italy, $200 \mathrm{p}$.

Hidayati, Nawansih, S.O., dan Febiana, V., Febiana. 2015. Teknik Pemanenan Mikroalga Nannochloropsis sp. yang Dikultivasi dalam Media Limbah Cair Karet Remah dengan Flokulan Aluminium Sulfat. Jurnal Teknologi Industri dan Hasil Pertanian, 20(2):1-7. doi: 10.23960/jtihp.v20i2.97 - 108

Huang, W.W., Dong, B.Z. Caidan, Z.P. \& Duan, S.S. 2011. Growth Effect on Mixed Culture of Dunaliella salina and Phaeodactylum trucornutum Under Different Inoculation Densities and Nitrogen Concentrations. African Journal of Biotechnology , 10:13164 -13174. doi: 10.5897/AJB10.2231

Isnansetyo, A. \& Kurniastuty. 1995. Teknik Kultivasi Fitoplankton dan Zooplankton. Kanisius, Yogyakarta, $116 \mathrm{hlm}$.

Istirokhatun, T., Aulia, M. \& Sudarno. 2017. Potensi Chlorella sp. untuk Menyisihkan COD dan Nitrat dalam Limbah Cair Tahu. Jurnal Presipitasi : Media Komunikasi dan Pengembangan Teknik Lingkungan, 14(2): 88-96. doi: 10.14710/presipitasi.v14i2.88-96

Kawaroe, M., Partono, T., Sunudin, A., Wulan, D.S., \& Augustine, D. 2010. Mikroalga :
Potensi dan Pemanfaatannya untuk Produksi Bio Bahan Bakar. IPB Press, Bogor. $50 \mathrm{hlm}$.

Kordi, G. 2010. Pakan Udang Nutrisi, Formulasi, Pembuatan, Pemberian Nutrien. Akademia, Jakarta. $120 \mathrm{hlm}$.

Kurniawan, M.H., Sriati, Agung, M.U.K. \& Mulyani, Y. 2017. Pemanfaatan Skeletonema sp. dalam Mereduksi Limbah Minyak Solar di Perairan. Jurnal Perikanan dan Kelautan, $8(2): 68-75$.

Kusdarwati, R., Bustaman, R.H., \& Arief, M. 2011. Pengaruh Perbedaan Warna Cahaya terhadap Pertumbuhan Kultivasi Spirulina sp. Jurnal Ilmiah Perikanan dan Kelautan, 3(2): $184-191$.

Lavens, P. \& Sorgeloos, P. 1996, Manual on The Production and Use of Live Food for Aquaculture, Fisheries Technical Paper, Food and Agriculture Organization of The United Nation, Rome, 295 p.

Liliandari, P. \& Aunurohim. 2013. Kecepatan Filtrasi Kerang Hijau Perna viridis terhadap Chaetoceros sp dalam Media Logam Tercemar Kadmium. Jurnal Sains Dan Seni Pomits, 2(2):149-154. doi: 10.12962/j23373 520.v2i2.3957

Lim, K.C. \& Zaleha, K. 2013. Effect of Photoperiod on The Cellular Fatty Acid Composition of Three Tropical Marine Microalgae. Malaysian Applied Biology, 42 (1):41 - 49 .

Maleta, H. S., Indrawati, R., Limantara, L. \& Brotosudarmo, T.H.P. 2018. Ragam Metode Ekstraksi Karotenoid dari Sumber Tumbuhan dalam Dekade Terakhir (Telaah Literatur). Jurnal Rekayasa Kimia dan Lingkungan, 13 (1):40-50. doi: 10.23955/rkl.v13i1.10008

Mata, T.M., Martins, A.A. \& Caetano, N.S. 2010. Microalgae for Biodiesel Production and Other Applications : A review. Renewable and Sustainable Energy Reviews. 1(1):1-20. doi: 10.1016/j.rser.2009.07.020

Muchammad, A., Kardena, E. \& Rinanti, A. 2013. Pengaruh Intensitas Cahaya Terhadap Penyerapan Gas Karbondioksida oleh Mikroalga Tropis Ankistrodesmus sp. dalam Fotobioreaktor. Jurnal Teknik Lingkungan, 19(2):103-116. doi: 10.5614/jt1.2013.19.2.1

Muyassaroh, Dewi, R.K., \& Anggorowati, D., 2018. Kultivasi Mikroalga Spirulina platensis dengan Variasi Pencahayaan Menggunakan Lampu TL dan Matahari. Dalam : Prosiding Seminar Nasional 
Aplikasi Sains \& Teknologi (SNAST) di Yogyakarta Tanggal 15 September 2018. IST AKPRIND, Yogyakarta, pp. $381-386$.

Nielsen, J.C. \& Nielsen, J. 2017. Development of Fungal Cell Factories for the Production of Secondary Metabolites : Linking Genomics and Metabolism. Synthetic and Systems Biotechnology, 2:5-12. doi: 10.1016/j.synb io.2017.02.002

Padang, A., La Dari, A. \& Latuconsina, H., 2013. Pengaruh Intensitas Cahaya yang Berbeda terhadap Pertumbuhan Navicula sp. Skala Laboratorium. Bimafika, 5(1):560-565.

Pal, S. W., Singh, N.K., \& Azam, K. 2013. Evaluation of Relationship Between Light Intensity (Lux) and Growth of Chaetoceros muelleri. Oceanography and Marine Research, 1(3):1-4. doi: 10.4172/2332-2632. 1000111

Parsons, A.J. \& Chapman, D.F. 2000. The Principles of Pasture Growth and Utilization. In: A. Hopkins (Editor). Grass its Production and Utilization. Ed 3rd. Blackwell Science Institure of Grassland and Environment Research, North Wyke, Okehampton Devon, $440 \mathrm{p}$.

Peri, P.L., Pastur, G.M., \& Lencinas M.V., 2009. Light Intensities and Water Status of Two Main Nothofagus Species of Southern Patagonian Forest, Argentina. Journal of Forest Science, 55(3):105-107. doi: 10.17221 /66/2008-JFS

Pertamawati. 2010. Pengaruh Fotosintesis terhadap Pertumbuhan Tanaman Kentang (Solanum tuberosum L.) dalam Lingkungan Fotoautotrof Secara Invitro. Jurnal Sains dan Teknologi Indonesia, 12(1):31-37. doi: 10.29122/jsti.v12i 1.848

Prayitno, J. 2015. Pola Pertumbuhan dan Pemanenan Biomassa dalam Fotobioreaktor Mikroalga untuk Penangkapan Karbon. Jurnal Teknologi Lingkungan, 17(1):45-52. doi: 10.29122/jtl.v17i1.1464

Prihantini, N.B., Rachmayanti, W. \& Wardhana, W. 2007. Pengaruh Variasi Fotoperioditas terhadap Pertumbuhan Chlorella dalam Medium Basal Bold. Jurnal Biota, 12(1):32 - 39.

Rafaelina, M., Rustam, Y. \&Amini, S. 2016. Pertumbuhan dan Aktivitas Antioksidan dari Mikroalga Porphyridium cruentum dan Chlorella sp. Bioma, 12(1):12-21. doi: 10.21009/Bioma11(1).2
Salim, M., Dharma, A. \& Putri, A.W. 2018. Studi Karakteristik Pertumbuhan Empat Jenis Species Mikroalga dan Uji Aktivitas Antimikroba. Jurnal Zarah, 6(2):53-58.

Setyaningsih, I., Desniar, \& Purnamasari, E., 2012. Antimikroba dari Chaetoceros gracilis yang Dikultivasi dengan Lama Penyinaran Berbeda. Jurnal Akuatika, 3(2):180-189.

Sinaga, L., Putriningtias, A. \& Komariyah, S. 2020. Pengaruh Intensitas Cahaya terhadap Pertumbuhan Nannochloropsis sp. Jurnal Akuakultura, 4(2):31-37.

Sopian, T., Junaidi, M. \& Azhar, F. 2019. Laju Pertumbuhan Chaetoceros sp. pada Pemeliharaan dengan Pengaruh Warna Cahaya Lampu yang Berbeda. Jurnal Kelautan, 12(1):36-44. doi: 10.21107/jk.v12 i1.4873

Sudhakar K., Suresh, S. \& Premalatha, M. 2011. An Overview of $\mathrm{CO}_{2}$ Mitigation Using Algae Cultivation Technology. International Journal of Chemical Research, 3:110-117.

Sunarto. 2004. Efisiensi Pemanfaatan Energi Cahaya oleh Fitopankton dalam Proses Fotosintesis. Jurnal Akuatika, 2(2):1-4.

Sureshkumar, S., Jasmin, B., Rahiman, K.M.M., \& Mohammed, A.A.H. 2014. Growth Enhancement of Microalgae, Chaetoceros calcitrans and Nannochloropsis oculata, using Selected Bacterial Strains. International Journal of Current Microbiology and Applied Sciences, 3(4): 352-359.

Taw, N. 1990. Petunjuk Pemeliharaan Kultur Murni dan Massal Mikroalga Proyek Pengembangan Udang, United Nations Development Programme, Food and Agriculture Organizations of the United Nations.

Trikuti, I.K., Anggreni, A.A.M.D. \& Gunam, I.B. W. 2016. Pengaruh Jenis Media terhadap Konsentrasi Biomassa dan Kandungan Protein Mikroalga Chaetoceros calcitrans. Jurnal Rekayasa Dan Manajemen Agroindustri, 4(2):13-22.

Wang, H, Fu, R. \& Pei, G. 2012. A Study on Lipid Production of the Mixotrophic Microalgae Phaeodactylum tricornutum on Various Carbon Sources, African. Journal of Microbiology Research, 6(5):1041-1047. doi: 10.5897/AJMR11.1365

Widyaningrum, N.F., Susilo, B. \& Hermanto, M.B. 2013. Studi Eksperimental Fotobioreaktor 
Photovoltaic untuk Produksi Mikroalga (Nannochloropsis oculata). Jurnal Bioproses Komoditas Tropis, 1(2):30-38.

Wu, H. 2016. Effect of Different Light Qualities on Growth, Pigment Content, Chlorophyll
Fluorescence, and Antioxidant Enzyme Activity in The Red Alga Pyropia haitanensis (Bangiales, Rhodophyta). Biomed Research International, Article ID 7383918, 8 pages. doi: $10.1155 / 2016 / 7383918$ 